\title{
Kesenjangan Digital di Kalangan Guru SD dengan Rentang Usia 20-58 Tahun di kecamatan Rajabasa
}

\author{
Zulfa Hazizah \\ Pendidikan Guru Sekolah Dasar, Fakultan keguruan dan Ilmu Pendidikan, Universitas PGRI Yogyakarta \\ Email: zulfahazizah272@gmail.com
}

Henry Aditia Rigianti

Pendidikan Guru Sekolah Dasar, Fakultan keguruan dan Ilmu Pendidikan, Universitas PGRI Yogyakarta Email: henry@upy.ac.id

\begin{abstract}
Abstrak
Teknologi Informasi dan komunikasi berkembang pesat di masyarakat. Tidak semua kalangan mampu beradapsi dengan perkembangan teknologi. Hal ini menjadi faktor dari kesenjangan digital, sehingga muncul istilah baru yakni gagal teknologi (gaptek). Kesejangan digital merupakan ketidak mampuan individu dalam merasakan manfaat dari teknologi informasi karena kurangnya akses dan kemampuan dalam penggunaan TIK. Kesenjangan digital karena belum tersedianya dana dan sumber daya yang mendukung lembaga pendidikan serta sarana dan prasarana yang terkait dengan infrastruktur komunikasi berbasis TIK yang terbatas, dan yang menjadi kendala yakni belum siapnya budaya dan kultur penggunaan dan pemanfatan TIK. Penelitian ini untuk melihat kesenjangan digital yang terjadi di kalangan guru di Kabupaten Lampung Selatan Kecamatan Rajabasa. Penelitian ini dikaji berdasarkan dari teori dan pendapat ahli, mengenai kesenjangan digital pada guru senior dan guru junior yang begitu signifikan dalam pengoprasian perangakat TIK.
\end{abstract}

Kata kunci: Kesenjangan digital, hardware, software, useware

\section{PENDAHULUAN}

Perkembangan Teknologi Informasi dan Komunikasi (TIK), berkembang pesat beriringan dengan perkembangan peradaban manusia Hal ini sangatlah berpengaruh terhadap kehidupan masyarakat saat ini (Fitriyadi, n.d.). Setiap inovasi yang diciptakan untuk memberikan manfaat positif bagi kehidupan manusia, agar memberikan banyak kemudahan dalam melakukan aktifitas manusia, sehingga lebih efektif dan efisien, dalam mencapai tujuanya.

Teknologi informasi dan komunikasi merupakan sarana dan prasarana yang meliputi ( Hardware, software, useware ) sistem dan metode untuk memperoleh mengirimkan dan mengolah data secara bermakna.TIK mencakup dua aspek yaitu teknologi informasi dan teknologi komunikasi, teknologi informasi berkaitan dengan proses, penggunaan sebagai alat bantau, manipulasi dan pengelolaan informasi, sedangkan teknologi komunikasi merupakan segala sesuatu berkaitan dengan penggunaan alat bantu untuk proses dan mentransfer data dari prangkat satu ke perangkat yang lain (Huda, 2020). Komunikasi digunakaan dalam dunia pendidikan dengan memanfaatkan media media komunikasi seperti computer, internet, e-mail, smart phone dan lainya, sehingga pembelajara dapat dilakukan dengan jarak jauh (Marryono Jamun, 1996).

Perkembangan TIK menuntut guru sebagai pendidik, harus memiliki kompetensi sebagai penunjang peserta didik sesuai dengan stadar kompetensi. Menurut UU No.14 Tahun 2005 pasal 10 ayat 1, (Mulyani, 2015). Kompetensi yang harus dimiliki oleh guru meliputi kompetensi pedagogik, kompetensi kepribadian, kompeteni sosial dan kompetensi profesional yang diperoleh melalui pendidikan profesi (Fitriyadi, n.d.). Teknologi dalam dunia pendidikan juga ditandai dengan hadirnya elearning. E-learning merupakan model pembelajran yang memanfaatkan media teknologi komunikasi dan informasi khususnya 
internet yang telah memfasilitasi perubahan dalam pembelajaran yang di sampaikan melalui berbagai media elektronik antara laian audio/visual, TV intraktif, Compeact Disc (CD) dan internet (Marryono Jamun, 1996).

Teknologi informasi dan komunikasi adalah sarana dan prasarana yang meliputi ( Hardware, software, useware ) sistem dan metode untuk memperoleh mengirimkan dan mengolah data secara bermakna Dalam era digital guru SD di tuntut meningkatkan kemampuanya untuk menguasai Teknologi Informasi. Dengan adanya literasi digital dapat dijadikan motivsi guru dalam rangka melek teknologi dan sebagai upaya untuk meningkatkan peserta didik untuk belajar (Pohan \& Suparman,2020) .

Kesenjangan digital (Digital Divide) merupakan ketidak mampuan individu dalam merasakan manfaat dari teknologi informasi ( Hadiyat, 2014). Melalui laporan dari The National Telecommunication And Information Administrasion (NTIA) yakni dari Ameri Serikat yang mengontrol bidang telekomunikasi dan informasi, masalah dari kesenjangan digital bukan hanya dari infrastruktur saja melainkan perbedaan penggunaan internetnya sehingga dapat menunjang desiminasi imu pengetahuan (Rahadian, 2017)

Permasalahan yang sering muncul dalam penerapan TIK yaitu belum siapnya budaya dan kultur di dalam pendidikan. Sehingga yang jadi fokus utama dalam pemahan terhadap TIK di dalam pendidikan adalah budaya dan kultur para guru secara penuh dalam pembelajaran (Munir, 2014).

\footnotetext{
Kesenjangan digital di kalangan guru, tidak semua guru mampu dalam mengintegrasikan TIK dalam proses pembelajran, khsusnya para guru senior dan para guru junior, kemampuan guru senior memanglah memiliki pengalaman yang banyak karna sudah
}

bertahun-tahun mengajar tentu sudah paham dengan prinsip-prinsip mendidik peserta didik. Namun guru junior yang masih baru menyelsaikan studinya di bangku kuliah mereka banyak mempelajari ilmu-ilmu baru di bangku pekuliahan dan masih minim pengalaman dalam mendidik tetapi mereka cukup baik dalam penguasaan Teknologi Informasi dan Komunkasi dan membuat guru junior lebih kreatif (Pakem, 2018)

Pengembangan kemampuan dalam menguasi teknologi informasi dan komunikasi seorang guru sangat berpengaruh pada kemampuan hard skill dan soft skill nya (Karakter \& Homeschooling, 2016). Soft skil adalah kepribadian secara personal serta kemamapuan keterampilan dan kecakapan yang digunakan dalam berintraksi dan berkomunkasi di lingkungan sedangkan hard skill merupakan kemampuan spesifik yang harus kita miliki dengan mempelajari secara formal. (Seorang guru kemampuan soft skillnya di gunakan ketika berkomunikasi dengan peserta didik serta memiliki prilaku yang baik karna bagaimanapun sifat seorang guru di sekolah dasar sangat di perhatikan oleh peserta didik dan juga di tiru oleh siswa. Sedangkan hard skill nya yaitu kemampuan dan penguasaan dalam penggunaan teknologi informasi dan komunikasi. Yaitu dalam mengoprasikan perangkat pembelajaran. Serta Pengembangan pembelajaran dengan perangkat elektronik dan jaringan internet.

Kesenjangan digital di Kabupaten Lampug Selatan khususnya di kecamatan Rajabasa, kesenjangan ini terlihat pada guru senior dan guru junior sangatlah jelas. Pasalnya banyak guru senior merasa kesulitan dalam penggunaan atau pemanfaatan teknologi informasi dan kominikasi. Di dalam kelas guru senior cenderung menggunakan pembelajaran dengan metode ceramah dimana metode ini hanya guru yang aktif dan membuat siswa menjadi pasif. Berdasarkan latar belakang di atas 
penulis ingin meneliti lebih dalam mengenai kesenjangan tersebut dengan judul “ Kesenjangan Digital Di Kalangan Guru SD Dengan Rentang Usia 20-58 Tahun di Kecamatan Rajabasa".

\section{Tenaga pendidik}

Guru merupakan seorang pendidik yang harus memiliki kompetensi-kompetensi dengan standar kependidikan, sesuai UU No 14 tahun 2005 pasal 10 ayat (Mulyani, 2015). Kompetensi yang harus dimiliki seorang guru merupakan kompetensi pedagogik, kompetensi kepribadian, kompetensi sosial dan kompetensi professional yang diperoleh melalui pendidikan profesi.pendidik atau guru memiliki tugas yaitu mendidik mengajar, membimbing, melatih, mengarahkan, menilai, mengevaluasi peserta didiknya (Marryono Jamun, 1996). Guru merupakan orang yang berpengaruh penting terhadap proses kegiatan belajar mengajar, seorang guru memiliki tanggung jawab terhadap perkembangan peserta didiknya baik dalam ranah kognitif, afektik maupun ranah psikomotorik (Azizah, 2020).

\section{Kesenjangan digital}

Terdapat tiga penelitiaan yang berhubugan dengan penelitian ini. Pertama penelitian yang dilakukan oleh Muhamad Zulham "Kesenjangan Digital di Kalangan Guru SMP" dari hal tersebut bahwa kesenjanagn digital yang terjadi dalam penggunaan Teknonologi informasi dan komunikasi bukan dari faktor aksebilitas melainkan dari faktor kapabilitas dimana para guru masih belum mampu mengoprasikan berbagai teknologi informasi yang ada.

Kedua, penelitian dari Dendi "Pengaruh Kesenjangan Digital (Digital Divide) Terhadap Internet Literacy Guru SMA Negri Di Kota Bandar Lampung" hasil penelitian tersebut bahwa yang menjadi faktor kesenjangan digital bukanlah dari kelengkapan fasilitas belajar mengajar yang berhubungan dengan ICT melainkan dari motivasi dari guru. Motivasi ini yang sangat mempengaruhi ICT Literacy yang merupakan jembatan antara literasi teknis dan melek informasi atau akses evaluasi dan penggunaan informasi dengan penggunaan teknologi (Fadilla et al., 2020).

Penelitian ketiga yang di tulis oleh Tanti Nurhayati berjudul "Problematika Guru Dalam Menguasai TIK (Teknologi Informasi dan Komunikasi) Pada Pembelajaran Agama Islam Dan Solusinya di MI Al-Asy'ari Kuniran Batangan Kabupaten Pati Tahun Ajaran 2015/2016". Berdasarkan hasil penelitianya bahwa problem utama dalam pemanfaatan TIK adalah terdapat pada kemampuan masingmasing guru. Kendala kedua yaitu faktor usia guru, guru yang usianya sudah relaif tua cendrung gagap teknologi sehingga sulit dalam menggunakan sarana TIK dalam pembelajaran.

Tujuan dari penelitian ini adalah:

1. Menggambarkan kesenjangan digidal pada guru di SD di kecamatan Rajabasa

2. Mengungkapkan perbedaan kemampuan guru dalam penggunaan sarana TIK rentang usia 24-58 tahun

\section{METODE}

Penelitian ini dilaksanakan di SD seKecamatan Rajabasa Kabupaten lampung Selatan penelitian ini menggunakan penelitia Kualitatif yaitu mengenai kesenjangan digital yang meliputi guru yang memiliki kemampuan dalam penggunaan digital dengan baik atau tidak . Sampel dari penelitian ini adalah guru, dalam penentuan subjek dilakukan secara sederhana. Terdapat enam sumber bukti yang dapat dijadkan fokus dalam pengumpulan data yaitu dokumentasi, wawancara, observasi langsung, observasi pemeran, arsip dan perangkat fisik (Kurniawan \& Setyawan, 2019). Adapun dalam penelitian ini meggunakan metode jenis pengumpulan data dengan wawancara, yaitu 
pengumpulan data yang dilakukan dengan tanya jawab secara langsung kepada guru SD di Kecamatan Rajabasa.Dengan tanya jawab secara langsung kepada guru baik guru senior maupun gurur junior, adapun informal peneliti, teknik penelitian informa dalam penelitian ini adalah memilih guru degan usia tertentu untuk dijadikan sampel penelitian,dengan keriteria tertentu sebagai subjek yaitu memilih guru dengan usia dengan kisaran 25-58 tahun dari sekolah SD di kecamatan Rajabasa.

Penelitian ini juga menggunakan teknik dengan analisis deskriptif yaitu menjelaskan faktorfaktor dari penyebab kesenjangan digital di kalangan guru di kecamatan Rajabasa. Temuan dalam penelitian ini akan di analisis dengan komponen analisis data yang dikembangkan oleh Miles\&Human yaitu terdiri dari tiga sub proses yang saling berkaitan, taknik eduksi data, penyajian data, verifikasi data atau disebut penarikan kesimpulan. Pengujian dilakukan menggunakan Korelasi person (Karakter \& Homeschooling, 2016). Peneliti juga membandingkan kesenjangan digital antara dua kelompok guru yakni guru senior dan guru juior di Sekolah Dasar se-Kecamatan Rajabasa, penelitian ini peneliti menggunakan metode komparasi yaitu metode yang digunakan untuk membandingkan antara dua kelompok atau lebih dari satu variable tertentu.

Tabel 1.1 Jumlah Guru SD di kecamatan Rajabasa

\begin{tabular}{|l|l|c|}
\hline No & Nama Sekolah & $\begin{array}{c}\text { Jumah } \\
\text { guru }\end{array}$ \\
\hline 1 & SDN Kota Guring & 14 \\
\hline 2 & SDN 1Kunjir & 10 \\
\hline 3 & SDN 1 Waymuli & 10 \\
\hline 4 & SDN 2 Waymuli & 8 \\
\hline 5 & SDN 2 Kunjir & 7 \\
\hline 6 & SDN Banding & 10 \\
\hline 7 & SDN Batu Balak & 8 \\
\hline 8 & SDN Canggung & 9 \\
\hline
\end{tabular}

\begin{tabular}{|l|l|c|}
\hline 9 & SDN Canti & 8 \\
\hline 10 & SDN Cugung & 6 \\
\hline 11 & SDN Hargo Pancuran & 8 \\
\hline 12 & SDN Kerinjing & 6 \\
\hline 13 & SDN Pulau Sebuku & 5 \\
\hline 14 & SDN Rajabasa & 9 \\
\hline 15 & SDN Sukaraja & 18 \\
\hline 16 & SDN Tanjung Gading & 10 \\
\hline 17 & $\begin{array}{l}\text { SDN 1 Tejang Pulau } \\
\text { Sebesi }\end{array}$ & 13 \\
\hline 18 & $\begin{array}{l}\text { SDN 2 Tejang Pulau } \\
\text { Sebesi }\end{array}$ & 9 \\
\hline & Jumlah & 158 \\
\hline
\end{tabular}

Jumlah populasi dan sampel penelitian di kecamatan Rajabasa, di ambil berdasarkan data DAPODIK 2020/2021

Tabel 1.2 Usia (x) dan Lama Mengajar(y)

\begin{tabular}{|c|c|c|c|}
\hline NO & Nama & Usia & $\begin{array}{c}\text { Lama } \\
\text { mengajar }\end{array}$ \\
\hline 1 & & 20 tahun & 1 tahun \\
\hline 2 & & 21 tahun & 1 tahun \\
\hline 3 & & 21 tahun & 1 tahun \\
\hline 4 & & 23 tahun & 2 tahun \\
\hline 5 & & 25 tahun & 3 tahun \\
\hline 6 & & 25 tahun & 3 tahun \\
\hline 7 & & 25 tahun & 5 tahun \\
\hline 8 & & 25 tahun & 3 tahun \\
\hline 9 & & 27 tahun & 4 tahun \\
\hline 10 & & 28 tahun & 5 tahun \\
\hline 11 & & 29 tahun & 6 tahun \\
\hline 12 & & 35 tahun & 10 tahun \\
\hline 13 & & 35 tahun & 10 tahun \\
\hline 14 & & 36 tahun & 11 tahun \\
\hline 15 & & 40 tahun & 19 tahun \\
\hline 16 & & 45 tahun & 23 tahun \\
\hline 17 & & 45 tahun & 22 tahun \\
\hline 18 & & 47 tahun & 23 tahun \\
\hline 19 & & 48 tahun & 26 tahun \\
\hline 20 & & 50 tahun & 30 tahun \\
\hline 21 & & 52 tahun & 31 tahun \\
\hline
\end{tabular}




\begin{tabular}{|l|l|l|l|}
\hline 22 & & 52 tahun & 33 tahun \\
\hline
\end{tabular}

Berdasarkan data yang diperoleh dari koesioner yang di sebar melalui media online (googel form) di Kecamatan Rajabasa dapat diketahui bahwa responden pria berjumlah 6 orang atau sebesar 27,2 \% lebih kecil dibandingkan dengan responden wanita yang berjumlah 16 orang atau sebesar $72,7 \%$. Dapat di simpulkan bahwa wayoritas responden nya adalah wanita yaitu $72,7 \%$ dari keseluruhan responden.

\section{HASIL DAN PEMBAHASAN}

Hasil penelitian dilapangan melalui wawancara kepada salah satu guru senior di sekolah SD N Kerinjing kecamatan Rajabasa dengan inisial HY usia 56 tahun dan dengan lama nya mengajar selama 35 tahun. Kemampuan dalam penggunaan TIK memang cukup sulit untuk memepelajarinya bukan beraati tidak sama sekali mencoba, tetapi sudah berkali-kali untuk mempelajri menggunakan TIK contohnya dalam tes sertifikasi dalam tes tersebut mengerjakan soal dengan menggunakan komputer hal itu masih bisa di pelajari secara berkala, namun jika penggunaan TIK dalam penggembangan pembelajaran cukup rumit untuk di pelajarinya, pemerintah pun sudah ada upaya untuk mengatasinya dengan memberikan seminar-seminar serta langkah-langkah kepada guru-guru dalam penggunaan TIK dalam K13. Beliau mengatakan untuk memeahami Kurikulum k13 pun sangat rumit apalagi jika harus meggunakan TIK dalam pengaplikasianya.

Banyak faktor yang di alami oleh guru senior seperti faktor usia, faktor usia ini mempengaruhi daya ingat guru yang mungkin sudah berkurang sehingga sulit untuk mempelajari dan mengingat langkah-langkah yang di buat dalam pengembangan pembelajaran seperti bahan ajar, media pembelajaran, dan masih banyak lainya. Faktor bagi guru perempuan yang sudah senior, mereka merasa tidak ada waktu jika harus mempelajari TIK dalam pengembangan pembelajaran berbasis TIK karna jika suda di rumah, mereka banyak pekerjaan rumah yang harus di selsaikan sehingga tidak ada waktu luang untuk mempelajarinya. Faktor dari sekolah juga tidak menuntuk guru untuk menggunakan TIK, karana disekolah pun fasilitas TIK Seperti LCD, komputer, dan internet pun kurang memadahi. Selanjutnya yaitu faktor kebiasaan, maksudnya yaitu kebiasaan di dalam kelas dengan menggunakan metode konfensiaonal seperti ceramah, Tanya jawab dan demonstarasiyang di anggap cukup simple dalam kegiatan belajar mengajar di kelas.

Sedangakan dari Hasil wawancara guru junior di sekolah SD N Hargo Pancuran inisial EN dengan usia 28 tahun dan dengan lama masa mengajar selama 6 tahun, dalam kemampuan penggunaan TIK cukup baik karna selama kuliah sudah menggunakan Komputer sehingga dalam mengajar pun tidak kesulitan dalam membuat peraangkat pembelajaran seperti bahan ajar, RPP dan silabus, namun jika harus membuat bahan ajar yang berbasis TIK tidaklah memungkinkan jika harus di terapkan di kelas, karan fasilitas sepeti LCD, internet tidak tersedia di sekolah. Hal itulah yang menjadi kendala pada guru junior dalam mengaplikasikan media ajar berbasis TIK.

Dari hasil penelitian melalui gfoom di peroleh 22 responden

\section{Korelasi person}

Dari hasil perhitungan korelasi person dengan IBM SPSS sebagai berikut 


\section{Correlations}

\begin{tabular}{|c|c|c|c|}
\hline & & usia & $\begin{array}{c}\text { lama_ } \\
\text { mengaj } \\
\text { ar }\end{array}$ \\
\hline \multirow[t]{3}{*}{ usia } & $\begin{array}{l}\text { Pearson } \\
\text { Correlation }\end{array}$ & 1 & $.988^{* * *}$ \\
\hline & $\begin{array}{l}\text { Sig. (2- } \\
\text { tailed) }\end{array}$ & & .000 \\
\hline & $\mathrm{N}$ & 22 & 22 \\
\hline \multirow[t]{3}{*}{$\begin{array}{l}\text { lama_me } \\
\text { ngajar }\end{array}$} & $\begin{array}{l}\text { Pearson } \\
\text { Correlation }\end{array}$ & $\begin{array}{r}.988 \\
* *\end{array}$ & 1 \\
\hline & $\begin{array}{l}\text { Sig. (2- } \\
\text { tailed) }\end{array}$ & .000 & \\
\hline & $\mathrm{N}$ & 22 & 22 \\
\hline
\end{tabular}

**. Correlation is significant at the 0.01 level (2-tailed).

Nilai korelasi pearson sebesar 0,988 menunjukan kekuatan hubungan antara variable $\mathrm{x}$ dengan variable $\mathrm{y}$, karena sig. sebesar 0,000 lebih kecil dari 0,05 maka dapat disimpulkan bahwa kekuatan hubungan antara variable $\mathrm{x}$ dan y sangat signifikan.

Idikator kemampuan dan kecakapan guru SD dalam penggunaan teknologi informasi dan komunikasi di kecamatan Rajabasa

- Mengetahui, menguasai dan mengerti kurikulum TIK $(61,9 \%)$

- Mahir dalam mengoprasikan perangkat TIK ( $47,6 \%)$

- Kemampuan dalam memilih software pengajaran di kelas $(22,7 \%)$

- Mengetahui teknik-teknik pengajaran menggunakan komputer dan perangkat TIK lainya ( 47,6\%)

- Peka terhadap teknologi terkait dalam dunia pendidikan $(57,1 \%)$

\section{PENUTUP}

\section{Simpulan}

Kesenjangan digital di dalam dunia pendidikan yaitu penguasaan TIK oleh para guru, tidak semua guru mampu dalam mengintegrasikan TIK dalam proses pembelajran, khsusnya para guru senior dan para guru junior, kemampuan guru senior memanglah memiliki pengalaman yang banyak karna sudah bertahun-tahun hingga puluhan tahun didunia pendidikan tentu sudah hafal jelas dengan prinsip-prinsip mendidik peserta didik

Kesenjangan digital di Kabupaten Lampug Selatan khususnya di kecamatan Rajabasa, kesenjangan ini terlihat pada guru senior dan guru junior sangatlah jelas. Pasalnya banyak guru senior merasa kesulitan dalam penggunaan atau pemanfaatan teknologi informasi dan kominikasi. Di dalam kelas guru senior cenderung menggunakan pembelajaran dengan metode ceramah dimana metode ini hanya guru yang aktif dan membuat siswa menjadi pasif dan hanya menjadi pendengar.

Hasil penelitian dilapangan melalui wawancara dan melalui koesioner gform yakni baik guru senior maupun guru junior masih kesulitan dalam penggunaaan software sebagai pengajaran di kelas masih rendah yakni hanya $23,8 \%$ artinya dalam kegiatan pembelajaran di kelas guru belum memanfaatakan software secara maksimal.

\section{Saran}

Bagi guru sebaiknya pelajari media digital dan manfatkan software untuk bahan ajar sebagai penunjang kegiatan belajar-mengajar di sekolah sehingga kegiatan pembelajaran di lakukan lebih efektif dan menyenagkan.

\section{DAFTAR PUSTAKA}

Azizah, M. (2020). Pengaruh Kemajuan Teknologi Terhadap Pola Komunikasi Mahasiswa Universitas Muhammadiyah Malang (UMM). Jurnal Sosiologi Nusantara, 45-54.

Fadilla, N., Konsentrasi, M., Perpustakaan, I., \& Informasi, D. (2020). Kesenjangan Digital di Era Revolusi Industri 4.0 dan Hubungannya dengan Perpustakaan 
sebagai Penyedia Informasi. Libria, 12(1), Dan Pembelajaran, 2(1), 234-254. $1-14$.

Fitriyadi, H. (n.d.). Integrasi Teknologi Informasi Komunikasi dalam Pendidikan 269.

Hadiyat, Y. D. (2014). ketidakmerataan pengetahuan digital di Indonesia. Pekommas, 17(2), 81-90.

Huda, I. (2020). Research \& Learning in Primary Education Perkembangan Teknologi Informasi dan Komunikasi ( TIK ) Terhadap Kulaitas Pembelajaran Di Sekolah Dasar. Asmar, 2(1), 121-125.

Karakter, P., \& Homeschooling, M. (2016). Pendidikan Karakter Melalui Homeschooling. Journal of Nonformal Education, 2(1). https://doi.org/10.15294/jne.v2i1.5316

Kurniawan, S. D., \& Setyawan, A. A. (2019). Pengukuran Kesenjangan Digital Di Banyumas Untuk. Seminar Nasional Edusainstek, 308-314.

Marryono Jamun, Y. (1996). Dampak Teknologi Terhadap Pendidikan. 10, 48-52.

Mulyani, F. (2015). KONSEP KOMPETENSI GURU DALAM UNDANG-UNDANG NOMOR 14 TAHUN 2005 TENTANG GURU DAN DOSEN ( Kajian Ilmu Pendidikan Islam ). Jurna Pendidikan Universitas Garut, 03(01), 1-8.

Munir. (2014). Kerangka Kompetensi Tik Bagi Guru. In Alfabeta.

Pakem, M. S. (2018). Plagiat merupakan tindakan tidak terpuji kesenjangan digital di kalangan guru-guru sekolah menengah se-kecamatan pakem.

Pohan, S. S., \& Suparman. (2020). Perspektif Literasi Digital Bagi Guru Sekolah Dasar. Jurnal Ilmu-Ilmu Sejarah, Sosial, Budaya Dan Kependidikan, 7(1), 164-178.

Rahadian, D. (2017). Teknologi informasi dan komunikasi (tik) dan kompetensi teknologi pembelajaran untuk pengajaran yang berkualitas. Jurnal Teknologi Pendidikan 